Bangladesh J. Sci. Res. 27(1): 63-73, 2014 (June)

\title{
ASSESSMENT OF SOIL AND WATER QUALITY OF BARAPUKURIA COAL MINING SITE, DINAJPUR, BANGLADESH
}

\author{
Rowshon Shad Fardushe, Md. Mahbubul Hoque* and Shimul Roy \\ Department of Environmental Science and Resource Management, \\ Mawlana Bhashani Science and Technology University, Santosh, \\ Tangail-1902, Bangladesh
}

\begin{abstract}
From the field observation it is apparent that the color of coal leached drainage water and the agricultural land water are blackish and slightly blackish respectively, which pollutes surface water and the agricultural land. The study showed the present status of the water quality through analyzing different parameters including color, temperature, $\mathrm{pH}, \mathrm{EC}, \mathrm{DO}, \mathrm{TDS}, \mathrm{BOD}, \mathrm{COD}, \mathrm{Cl}^{-}$, $\mathrm{Cu}, \mathrm{Zn}$ and $\mathrm{Fe}$ as well as the status of soil quality where $\mathrm{pH}, \mathrm{OC}, \mathrm{PO}_{4}^{-}, \mathrm{Cu}, \mathrm{Cr}$ and $\mathrm{Zn}$ were analyzed. All the water quality parameters (e.g. temperature, $\mathrm{pH}$, EC, TDS, DO, and BOD) were within normal levels but the value of COD was higher, which affects the aquatic environment. The concentration of heavy metals in water varied with $\mathrm{Zn}>\mathrm{Cu}>\mathrm{Cr}$ and in soil the concentration varied with $\mathrm{Cu}>\mathrm{Cr}>\mathrm{Zn}$.
\end{abstract}

Key words: Coal, physico-chemical parameters, water quality, soil quality

\section{Introduction}

In developmental process coal mining is a major industry, which is contributing inadvertently towards the environmental pollution but also plays a vital role for the development of the country by assuring the energy supply (Tiwary 2001). Coal, a natural mineral resource, is a black or brownish-black rock that is formed from plants, which died about 100 to 400 million years ago (Ashton 1999). It is a heterogeneous mixture of several components such as sulfur, elemental carbon, arsenic, ash and heavy metals etc. (Ashton et al. 2001). Coal is a major fuel used for generating electricity worldwide. Coal provides around $27 \%$ of global primary energy need and generates about $36 \%$ of the world electricity (Tiwary 2001). Coal is valued for its energy content and is found in many countries of the world, but commercially it is extracted over 50 countries. Bangladesh is one of the top coal production countries and supply coal for its internal industrial energy source (Energy Information Administration 2005). The coal mining in the Barapukuria, north-west of Bangladesh, has a potentiality to resolve the current

\footnotetext{
*Corresponding author: <mmahbubul@gmail.com>
} 
energy crisis and improve the living standards of Bangladesh. It brings long term social and economical benefits to the people of Barapukuria, and the surrounding Upazilas of northern Bangladesh and to the nation as a whole (Haque 2007). Like many other industries coal mines are also treated as the polluting industries for quite long time. The principal environmental impacts associated with underground mining (e.g. coal) are linked to the mine wastes and blasting residues brought to the surface by mine dewatering activities (Ashton et al. 2001). Coal mining methods both opencast and underground affects the environment of the area. During the mining process huge amounts of water are discharged on the surface, which often contains high loads of TSS, TDS, hardness and heavy metals and consequently contaminates the surface and groundwater (Tiwary 2001).

The coal mine in Barapukuria is treated as a red category industry (ECR 1997). The mine wastes, mainly the polluted water adversely affects the surrounding agricultural land and water body. The cumulative effects of mining exploration activities at multiple sites within the area have the potential to drive the environmental changes. For instance, the more common and noticeable effects of these cumulative impacts include changes in aquatic and terrestrial ecosystem (Kibria et al. 2012). Generally, environmental impacts of mining exploration include the removal of vegetations for survey lines, vegetation damage and soil erosion due to vehicle tracks; abandon equipment and supplies, which also leads to the soil and water pollution and contamination. The International Accountability Project reports that mining operations at Barapukuria have destroyed roughly 300 acres of land, impacting about 2,500 people in seven villages, as land subsidence of over one meter in depth has destroyed crops and lands and damaged homes. The people in 15 villages have also apparently lost their access to water, as huge quantities of water pumped out for the Barapukuria mine, which consequently caused a rapid drop in water level (Akhtar 2000). However, the objectives of the study were to analyze the water quality of the coal mining site and to assess the soil quality of the mining site as well as the agricultural land.

\section{Materials and Methods}

Study area: Barapukuria coal miningsiteis located at Parbotipur Upazila of Dinajpur district, Bangladesh (Fig. 1). The mining site is located in flat paddy land of the northwestern corner of Bangladesh at about $45 \mathrm{~km}$ east of the district headquarters of Dinajpur. The area of the coal field is about $5.25 \mathrm{sq} \mathrm{km}$. In addition, the field area is suggested to have possible extension for 1 to $1.5 \mathrm{sq} \mathrm{km}$ to the south. (Anon. 1991). 
Data collection: To carry out the study primary data were attained through intensive field observation and laboratory work. However, apart from the primary data, the collection of secondary data was also very significant to carry out the study. Secondary data were collected from different sources (e.g. Barapukuria Coal Mining Company Ltd., Kibria et al. 2012, Tiwary 2001, Ashton et al. 2001, Akhtar 2000, Ashton 1999 and Anon. 1991).
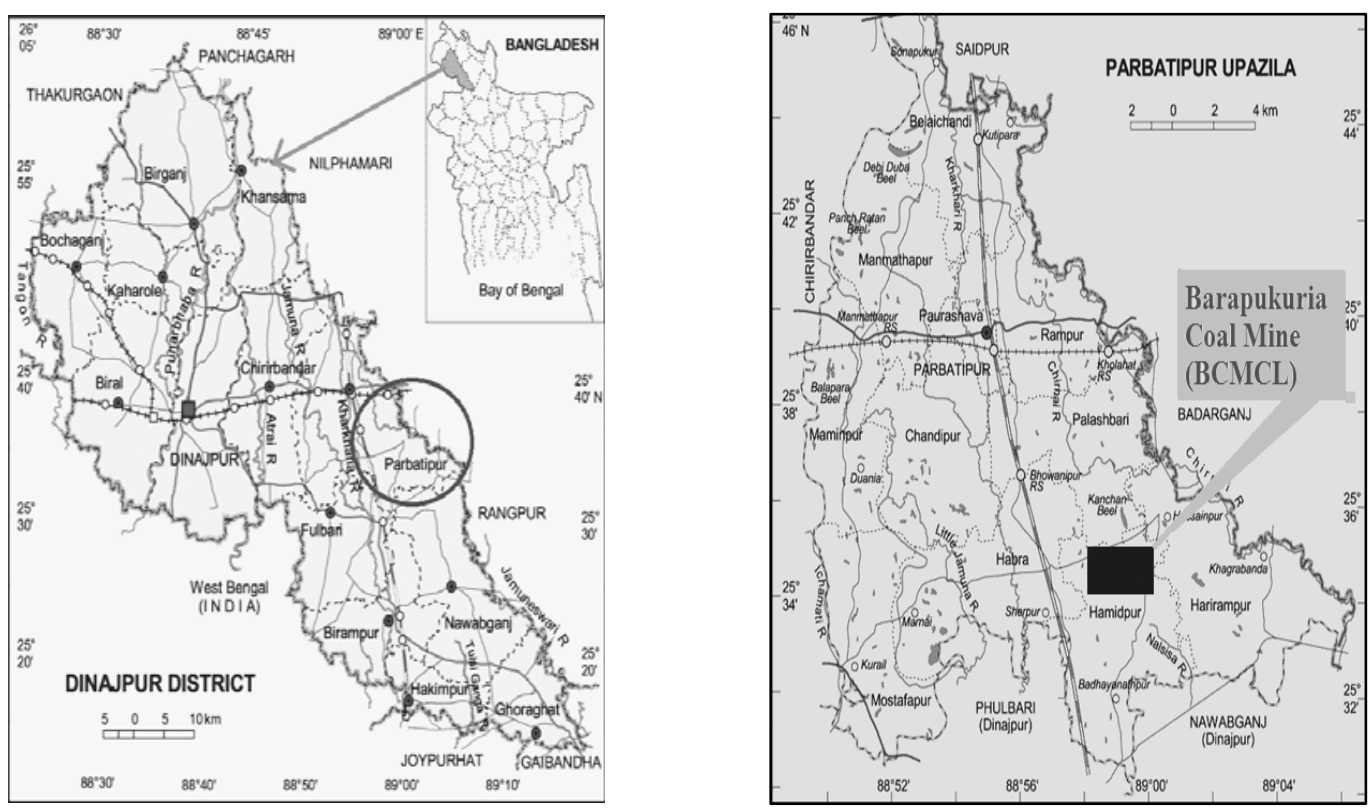

Fig. 1. Barapukuria coal mining site (Source: Banglapedia 2000).

Water sample collection: Water samples were collected in different environmental conditions from different points of the study area (Fig. 2). The mine discharged water samples were collected from outside the drain and the groundwater and surface water samples were also collected. The sample containing bottles were cleaned with dilute acid followed by distilled water. Before sampling the bottles were rinsed again three times with water to be sampled. Ninety $\mathrm{ml}$ of water sample from each bottle was transferred to $100 \mathrm{ml}$ plastic bottle, which contained $10 \mathrm{ml} 2 \mathrm{M}$ hydrochloric acid ( $\mathrm{HCl}$ ) solution for the analysis of $\mathrm{Cu}, \mathrm{Cr}, \mathrm{Fe}$ and $\mathrm{Zn}$. Potassium iodide (KI) solution was used to protect the water samples from any fungal and other pathogenic attack. In order to analyze the $\mathrm{pH}$, EC, TDS, DO and BOD water samples were carefully carried to the laboratory of the Department of Environmental Science and Resource Management (ESRM), Mawlana Bhashani Science and Technology University (MBSTU), Tangail and to analyze the 
heavy metals, $\mathrm{COD}$ and $\mathrm{Cl}^{-}$water samples were cautiously transported to the Department of Environment (DoE), Khulna.

Soil sample collection: Soil samples were collected in sealed polythene bags from different points of the study area (Fig. 2). Surface soil samples were collected from the nearby mine drainage. The agricultural land soil, which was irrigated with mine water or drain water, and the normal farmland soil were also collected for analysis. The samples were scraped from the top to bottom with the help of an auger. Samples were labeled properly including date of collection, location and code number of soil samples. In order to analyze the $\mathrm{pH}$, heavy metals $\left(\mathrm{Zn}, \mathrm{Cu}\right.$ and $\mathrm{Cr}$ ) and nutrient (e.g. $\mathrm{PO}_{4}{ }^{-}$) soil samples were cautiously transported to the Department of Environment, Khulna.

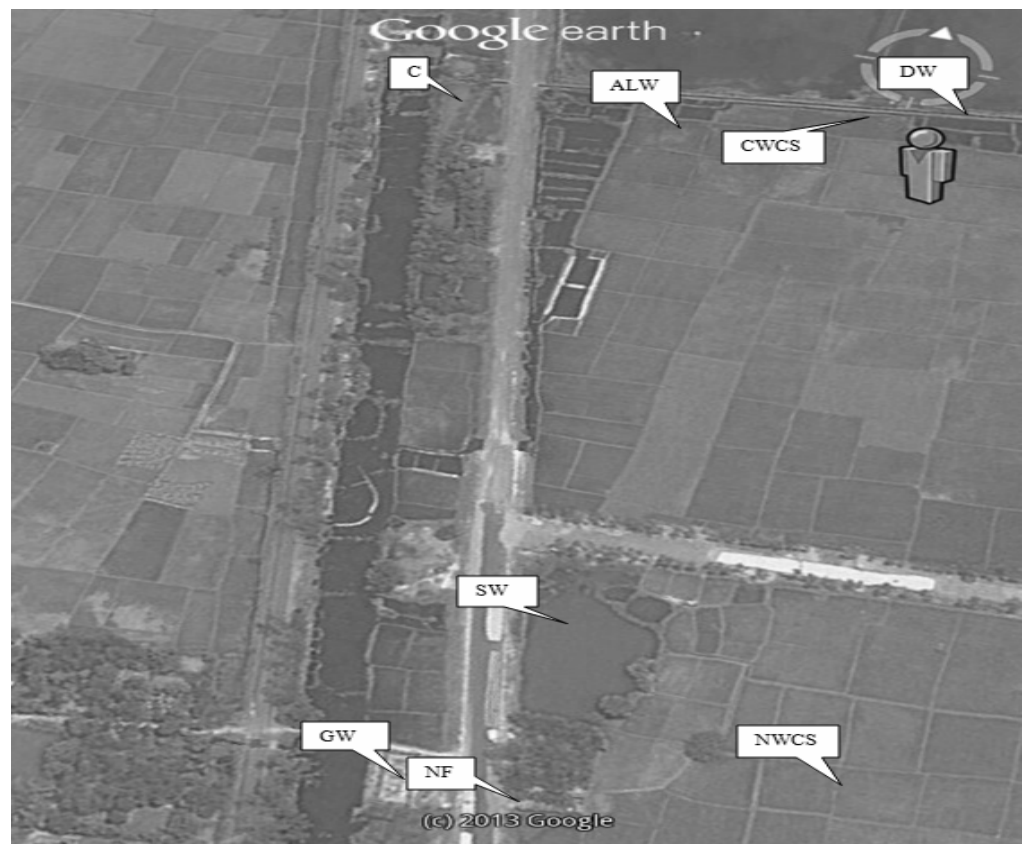

Fig. 2. Different sampling points in Barapukuria coal mining site $(\mathrm{DW}=$ Mine drainage water, ALW = Agricultural land water, GW = Groundwater, SW = Surface water, C = Coal sample, NF $=$ Normal field soil, CWCS $=$ Coal water cultivated soil and NWCS $=$ Normal water cultivated soil) (Source: Google Earth 2013).

Analytical methods: To analyze the physico-chemical parameters of water various standard methods were followed and a number of instruments were used. The water quality parameters such as temperature and $\mathrm{pH}$ were determined by the thermometer and digital $\mathrm{pH}$ meter, respectively. Electrical conductivity (EC) and total dissolved solids (TDS) were determined by digital EC and TDS meter (model-HM digital, Germany), 
respectively. Dissolve oxygen (DO) was determined by digital DO meter (model-D. 46974, Taiwan) where sodium thiosulphate $(0.025 \mathrm{~N})$ was used as a reagent. Alkalinity was measured by titration method and the EDTA method was used to determine the hardness of water. The biological oxygen demand (BOD) was measured by two steps where initial $\mathrm{BOD}\left(\mathrm{BOD}_{1}\right)$ was measured immediately after the sample collection and after 5 days $\mathrm{BOD}\left(\mathrm{BOD}_{5}\right)$ was measured by incubation in the dark condition at $20^{\circ} \mathrm{C}$ for 5 days. Then the total BOD (BOD $\left.1-\mathrm{BOD}_{5}\right)$ was measured according to Trivedy and Goel (1984).The chemical oxygen demand (COD) was determined by closed reflex chlorimatic method. The chloride was analyzed by the argentometric method. Copper $(\mathrm{Cu})$, zinc $(\mathrm{Zn})$, iron (Fe) and chromium (Cr) were measured through the atomic absorption spectrophotometer (model-UNICAM 969, England). Soil pH was determined by $\mathrm{pH}$ meter. The per cent of organic carbon was determined titrimetrically using Walkley and Black (1934)method. Phosphorus of water samples was determined colorimetrically by stannous chloride $\left(\mathrm{SnCl}_{2}\right)$ method based on the procedure outlined by Jackson (1973) and Tandon (1995). Zn, Cu, Cr and Fe were determined by the DTPA extraction method outlined by Huq and Alam (2005). Finally, data were compiled and analyzed by using the Microsoft Office Excel 2007.

\section{Results and Discussions}

Water sample: The colour of the water samples of coal leached drainage water appeared blackish and the agricultural land water samples appeared slightly blackish. Therefore, the water was unsuitable not only for aquaculture but also for domestic, industrial or agricultural purposes. However, the groundwater and surface water were colorless. The temperature recorded in water samples beside the mine drainage was $40^{\circ} \mathrm{C}$ whereas the temperature of agricultural land water, surface and groundwater was 32,25 and $22^{\circ} \mathrm{C}$, respectively (Table 1 ).

The $\mathrm{pH}$ values measured in Barapukuria coal mine industry showed that all of the samples have $\mathrm{pH}$ values of greater than 7 , which is slightly alkaline whereas the standard value of $\mathrm{pH}$ was 6 to 9 (ECR 1997). The $\mathrm{pH}$ value of mine drainaged water was recorded 7.55 whereas the $\mathrm{pH}$ values of agricultural land water, groundwater and surface water were 7.4, 7.45 and 7.52, respectively (Table 1), which reflects its suitability for aquatic life and for all types of water uses.

The EC and TDS at different sampling points were ranged from $204-370 \mu \mathrm{S} / \mathrm{cm}$ and 104-198 mg/l, respectively. The highest TDS (198 mg/l) and EC (370 $\mu \mathrm{S} / \mathrm{cm})$ were found in surface water and in mine drainaged water, respectively (Table 1).Water that contains less than $500 \mathrm{ppm}$ of dissolved solid is generally satisfactory for the domestic use and other industrial purposes and water containing more than $1000 \mathrm{ppm}$ of dissolved solids usually contains minerals that give it a distinctive taste or make it unsuitable for human 
consumption (Irshad et al. 2011) whereas the ECR (1997) defined the standard value of TDS for the inland surface water as $2100 \mathrm{mg} / \mathrm{l}$. As the total concentration of dissolved solids in water is a general indication of its suitability for any particular purpose, the result of the study concluded that the water at the downstream of the river is considered as suitable for fish culture and other purposes (Table 1).

Table 1. Water quality parameters from various sampling sites of Barapukuria coal mine area.

\begin{tabular}{|c|c|c|c|c|c|c|}
\hline \multirow{2}{*}{ Parameters } & \multicolumn{4}{|c|}{ Sampling points } & \multirow{2}{*}{ Mean \pm SD } & \multirow{2}{*}{ Range } \\
\hline & DW & ALW & GW & SW & & \\
\hline Temp $\left({ }^{0} \mathrm{C}\right)$ & 40 & 32 & 22 & 25 & $29.57 \pm 8.016$ & $22-40$ \\
\hline $\mathrm{pH}$ & 7.55 & 7.40 & 7.45 & 7.52 & $7.48 \pm 0.07$ & 7.40-7.55 \\
\hline $\mathrm{EC}(\mu \mathrm{S} / \mathrm{cm})$ & 370 & 362 & 204 & 360 & $324 \pm 80.2$ & $204-370$ \\
\hline TDS (mg/l) & 182 & 192 & 104 & 198 & $169 \pm 43.84$ & 104-198 \\
\hline DO (mg/l) & 5.67 & 6.66 & 7.67 & 8 & $7 \pm 1.054$ & $5.67-8$ \\
\hline COD (mg/l) & 438 & 795 & 0.00 & 273 & $376.5 \pm 332.4$ & $0.00-795$ \\
\hline Zn (mg/l) & 0.03 & 0.01 & 0.18 & 0.09 & $0.08 \pm 0.08$ & $0.01-0.18$ \\
\hline $\mathrm{Fe}(\mathrm{mg} / \mathrm{l})$ & 1.74 & 0.03 & 1.19 & 2.1 & $1.44 \pm 0.954$ & $0.03-1.74$ \\
\hline $\mathrm{Cu}(\mathrm{mg} / \mathrm{l})$ & 0.08 & 0.08 & 0.00 & 0.01 & $0.44 \pm 0.44$ & 0.00-0.08 \\
\hline $\mathrm{Cr}(\mathrm{mg} / \mathrm{l})$ & $\tilde{\mathbf{N}} 0.02$ & ÑD.01 & 0.00 & ÑD.01 & $\tilde{\mathbf{N}} .01 \pm 0.008$ & ND.02- 0.00 \\
\hline
\end{tabular}

DW $=$ Mine drainage water, ALW = Agricultural land water, GW = Groundwater and SW = Surface water .

Dissolved oxygen is an important parameter in water quality assessment and reflects the physical and biological processes prevailing in the water. The DO values also indicate the degree of pollution in water bodies. Adequate DO is necessary for good water quality, survival of aquatic organism and decomposition of waste by microorganism (Islam et al. 2010, Rahman et al. 2012). The DO of mine drainaged water was recorded $5.67 \mathrm{mg} / \mathrm{l}$ whereas the DO values of agriculture land water, groundwater and surface water were 6.66, 7.67 and $8.0 \mathrm{mg} / \mathrm{l}$, respectively (Table 1), which were within the standard values (4.5 - $8 \mathrm{mg} / \mathrm{l}$ ) (ECR 1997). Since less DO is available in the water, fish and other aquatic organisms may not survive. If there is no organic waste present in the water, there would not be as many bacteria present to decompose it and thus the BOD will tend to be lower and the DO level will tend to be higher (Rahman et al. 2012). But the investigated BOD values were found higher in the sample waters. The BOD of mine drainage water was recorded $26.65 \mathrm{mg} / \mathrm{l}$ whereas the BOD values of agricultural land water, surface and groundwater were 24.46, 24.92 and $22.31 \mathrm{mg} / \mathrm{l}$, respectively (Fig. 3). Unpolluted waters typically have BOD values of 2 ppm or less (Chapman 1996) was suitable for irrigation and BOD value of less than $50 \mathrm{mg} / \mathrm{l}$ is generally recommended for the inland surface water (ECR 1997). The result of the study revealed that in respect of irrigation the BOD values of all the water samples were higher than the standard value, which is not suitable for irrigation. The COD value of mine drainage water was recorded $438 \mathrm{mg} / \mathrm{l}$ whereas the COD value of the agricultural land water, groundwater and surface water was 795, 0 and 
$274 \mathrm{mg} / \mathrm{l}$, respectively (Table 1). The COD indicates the toxic condition and the presence of biologically resistant organic substances. The result of the study demonstrated that all of the COD values of different water samples except the groundwater exceeded the standard limit (200 mg/l) (ECR 1997), which consequently affect the aquatic life.

The investigated values of $\mathrm{Cl}^{-}$were found within the permissible limit, such as the chloride ion of mine drainage water was $24.75 \mathrm{mg} / \mathrm{l}$ whereas in the agricultural land water, groundwater and surface water the values were 28.98, 22.58 and $29.99 \mathrm{mg} / \mathrm{l}$, respectively (Fig. 3). However, the presence of chloride in the study area may results from the anthropogenic sources including agricultural run off, domestic and industrial wastes and leaching of saline residues in the soil (Appelo and Postma 1993).
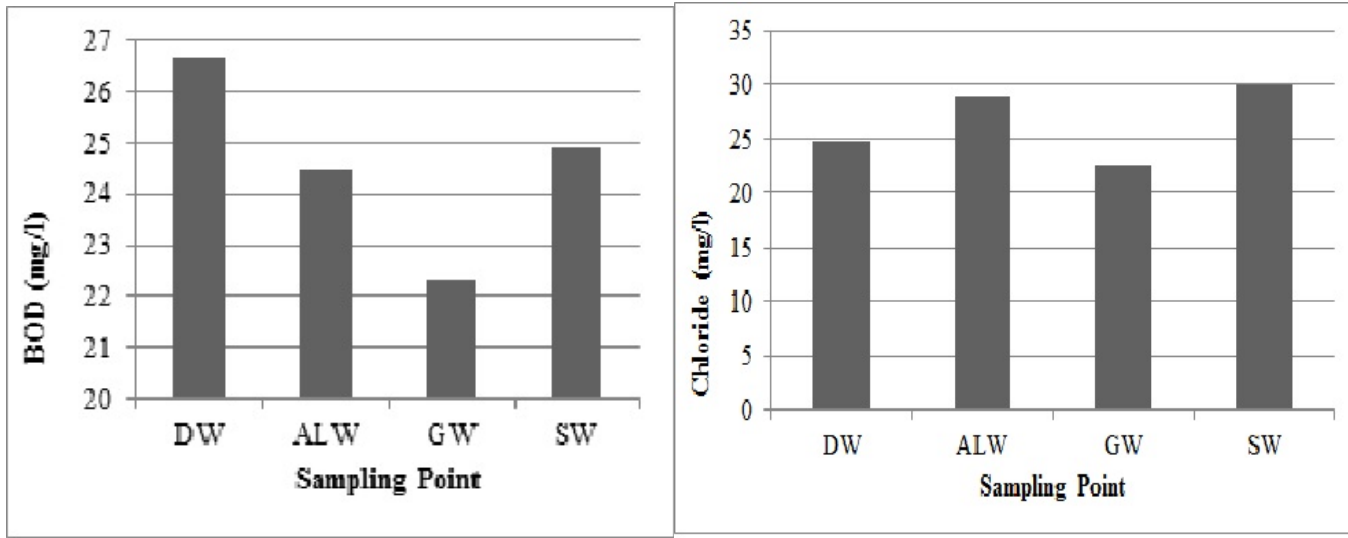

Fig. 3. The BOD and chloride $\left(\mathrm{Cl}^{-}\right)$values at different sampling points $(\mathrm{DW}=$ Mine drainage water, ALW = Agricultural land water, GW = Groundwater, and SW = Surface water).

The study found Fe concentration in the water samples from $0.03-1.74 \mathrm{mg} / \mathrm{l}$ with an average value of $1.44 \mathrm{mg} / \mathrm{l}$ (Table 1), which was below the recommended value and thus suitable for irrigation. For instance, the maximum recommended concentration of Fe in water used for irrigation is about $5.0 \mathrm{mg} / \mathrm{l}$ (Ayers and Westcot 1985). The highest concentration of $\mathrm{Zn}(0.03 \mathrm{mg} / \mathrm{l})$ was found in the mine drainage water, which was below the permissible limits and thus suitable for irrigation. For instance, Gibeault and Cockerham (1985) and ECR (1997) recommended that water should contain not more than $5.0 \mathrm{mg} / \mathrm{l} \mathrm{Zn}$ whereas Ayers and Westcot (1985) recommended the maximum permissible limit of $\mathrm{Zn}$ in irrigation water to be $2.00 \mathrm{mg} / \mathrm{l}$. On the other hand, the highest concentration of $\mathrm{Cu}(0.03 \mathrm{mg} / \mathrm{l})$ was found in both the mine drainage water and agricultural land water (Table 1$)$. This value was below the permissible limit $(0.2 \mathrm{mg} / \mathrm{l})$ as defined by the National Academy of Science (Gibeault and Cockerham 1985 and ECR 1997). 
Analysis of soil samples: The study revealed that soil collected from the normal field had $\mathrm{pH}$ value higher than the coal sample. The $\mathrm{pH}$ value of normal field soil was 5.60 whereas the $\mathrm{pH}$ of coal sample was 5.34 and the $\mathrm{pH}$ of coal water treated soil and normal water treated soil were 4.86 and 5.29, respectively (Fig. 4). Tisdale et al. (1999) recommends the optimum range of soil $\mathrm{pH}$ for crop production as $6.5-7.0$. However, the study also identified that with the increase in soil depth, the $\mathrm{pH}$ value decreased even further. Different factors like leaching action of wastes, soil nature, mechanical composition, etc. may be responsible for it (Goswami and Sarma 2008). The identified values of total organic carbon content in different soil samples such as coal sample, normal field soil, coal water treated soil and normal water treated soil were presented in Fig. 4. Within the different soil samples the highest value of organic matter content was observed in coal and lowest was in normal water treated soil and the figures were 19.53 and $1.47 \%$, respectively (Fig. 4 ).
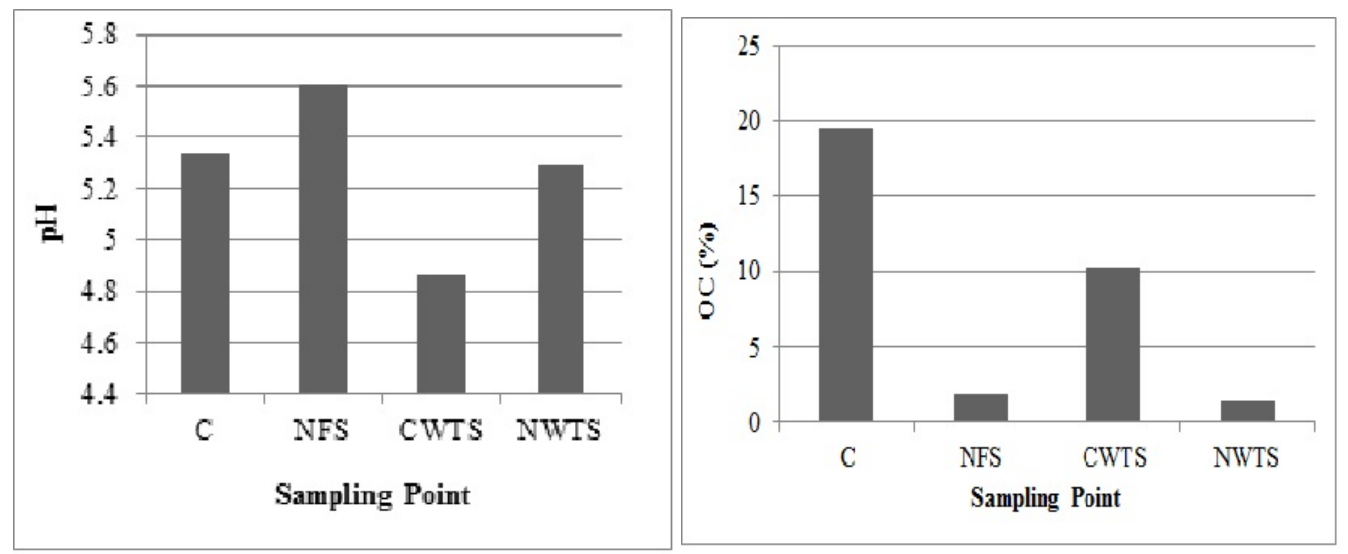

Fig. 4. Status of $\mathrm{pH}$ and total organic carbon (OC) contents in soil at different sampling points $(\mathrm{C}=$ Coal sample, NFS $=$ Normal field soil, CWTS $=$ Coal water treated soil and NWTS = Normal water treated soil).

The mean value of $\mathrm{PO}_{4}$ in all collected soil was found to be $0.0098 \mathrm{ppm}$. The value of $\mathrm{PO}_{4}{ }^{-}$in different soil samples ranges from $0.0097-0.0099 \mathrm{ppm}$ (Table 2), which was below the permissible limit (2.00 ppm).

Table 2. Soil quality parameters of various sampling sites of the study area.

\begin{tabular}{|c|c|c|c|c|c|c|}
\hline \multirow[b]{2}{*}{ Parameters } & \multicolumn{4}{|c|}{ Sampling points } & \multirow[t]{2}{*}{ Mean \pm Sd } & \multirow[t]{2}{*}{ Range } \\
\hline & $\mathrm{C}$ & NFS & CWCS & NWCS & & \\
\hline $\mathrm{PO}_{4}^{-}(\mathrm{ppm})$ & 0.0099 & 0.0097 & 0.0098 & 0.0099 & $0.0098 \pm 9.577 \mathrm{E}-05$ & 0.0097-0.0099 \\
\hline $\mathrm{Cu}(\mathrm{ppm})$ & 1.25 & 1.57 & 1.27 & 1.44 & $1.383 \pm 0.153$ & $1.25-1.57$ \\
\hline $\mathrm{Zn}(\mathrm{ppm})$ & 0.001 & 0.003 & 0.001 & 0.0025 & $0.0010 \pm 0.00103$ & $0.001-0.0025$ \\
\hline $\mathrm{Cr}(\mathrm{ppm})$ & 0.04 & 0.18 & 0.03 & 0.05 & $0.075 \pm 0.070$ & $0.03-0.18$ \\
\hline
\end{tabular}

C = Coal sample, NFS = Normal field soil, CWCS = Coal water cultivated soil and NWCS $=$ Normal water cultivated soil. 
The study identified a similar concentration of $\mathrm{Zn}(0.001 \mathrm{ppm})$ in the coal sample and coal water cultivated soil. In the normal field soil and normal water irrigated soil the concentration was found higher (0.003 and $0.0025 \mathrm{ppm}$ respectively) than the concentration found in coal and coal water irrigated soil (Table 2). The result of the study showed the highest concentration of copper $(1.57 \mathrm{ppm})$ in the normal field soil and the lowest concentration (1.25 ppm) in coal sample. However, in coal water irrigated farm soil and normal water irrigated soil the concentrations 1.27 and $1.44 \mathrm{ppm}$, respectively (Table 2). The concentration of chromium in different soil samples ranges from 0.03-0.18 ppm, whereas the highest concentration was observed in the normal field soil (0.18 ppm) and the lowest concentration was in the coal water irrigated farm soil (0.03 ppm) (Table 2). The presence of higher concentration of these heavy metals in soil may deteriorate its quality. For instance, Wang et al. (2001) reported that the heavy metals may cause soil pollution to a great extent by their accumulation.

\section{Conclusion}

The study showed the overall scenario regarding the concentration of different water quality and soil quality parameters resulted from the Barapukuria coal mine activity and their suitability for aquatic life as well as for irrigation. The results of the study concluded that the water and soil in the coal mine industrial area were found quitely contaminated, which can deteriorate the aquatic life and agriculture. The study showed that all the water quality parameters of mining area i.e. temperature, $\mathrm{pH}$, EC, TDS, DO, BOD were in standard levels, while the value of COD was higher. However, in respect of irrigation the identified BOD values were found higher in the sample waters. For instance, the BOD of mine drainage water, agricultural land water, surface and groundwater was recorded as 26.65, 24.46, 24.92 and $22.31 \mathrm{mg} / \mathrm{l}$ respectively, whereas Chapman (1996) recommended the BOD value of $2.0 \mathrm{ppm}$ or less for suitable irrigation. The study also demonstrated that all of the COD values of different water samples except groundwater exceed the standard limit (200 mg/l), which consequently affect the aquatic life. The average concentration of $\mathrm{Cu}, \mathrm{Fe}$ and $\mathrm{Zn}$ content in the water samples was below the standard level. The study identified that the $\mathrm{pH}$ of the soil samples were in permissible level and thus suitable for agriculture. Although the concentration of heavy metals (e.g. $\mathrm{Cr}, \mathrm{Zn}$ and $\mathrm{Cu}$ ) in the soil samples was in permissible limits, however the study depicted that high levels of these heavy metals from the coal mine can pose a serious threat on the environment within a short period of time.

\section{Acknowledgements}

Authors are grateful to Dr. Torun Kanti Sikder (Director) and Syed Ahmmad Kabir (Senior Chemist), Department of Environment (DoE), Khulna, Bangladesh for providing the laboratory facilities and kind cooperation during the study period. 


\section{References}

Akhtar, A. 2000. Coal and hard rock resources in Bangladesh. Geological Survey of Bangladesh, 153 Pioneer road, Dhaka, Bangladesh.

Anon. 1991. Techno-economic study of Barapukuria Coal project, Dinajpur, Bangladesh. Wardel Armstrong, Vol.1, chaps. 1 and 2.

Appelo, C. A. J. and D. Postma. 1993. Geochemistry, groundwater and pollution. A. A. Balkema Publisher, USA.

Ashton, P. J. 1999. Using environmental impact assessment to determine the consequences of mining activities and highlights the costs of sustainable development. In: Proceedings of the Conference of the Environmental Management System in Mining, 11-13 October, Kempton park, South Africa, p. 12.

Ashton, P.J., D. Love, H. Mahachi, P.H.G.M. Dirks. 2001. An overview of the impact of mining and mineral processing operations on water resources and water quality in the Zambezi, Limpopo and Olifants catchments in Southern Africa. Contract Report to the Mining, Minerals and Sustainable Development (Southern Africa) project by, CRIS environment.

Ayers, R.S. and D. W. Westcot. 1985. Water quality for agriculture, FAO irrigation and drainage paper. 29 (Rev. 1): 4096.

Banglapedia. 2000. The National encyclopedia of Bangladesh. [Available online at]:http://mapsof-bangladesh.blogspot.com/search?q=Map+of+Dinajpur+District

Chapman, D. 1996. Water Quality Assessment: A guide to the use of biota, sediments and water in environmental monitoring. ${ }^{\text {nd }}$ Edition, UNESCO/ WHO/ UNEP.

ECR (Environment Conservation Rules). 1997. Government of the People's Republic of Bangladesh. Ministry of Environment and Forest.

Energy Information Administration Reports. 2005. The official energy statistics of the U. S. Government.

Gibeault, V.A. and S. T. Cockerham. 1985. Turfgrass, Water conservation. ANR Publications, University of California. p. 155.

Google Earth. 2013. Google Earth Map-Barapukuria Coal mine, data SIO, NOAA, U.S. Navy, NGA, GEBCO.

Goswami, U. and H. P. Sarma. 2008. Study of the impact of municipal solid waste dumping on soil quality in Guwahati city. Poll. Res. 27(2):327-330.

Haque, M. I. 2007. The coal debate in Bangladesh. New age (Bangladesh). 25 ${ }^{\text {th }}$ October 2007.

Huq, S. M. I. and M. D. Alam. 2005. A handbook on analyses of soil, plant and water. BACERDU, University of Dhaka, Bangladesh. pp. 119-120.

Irshad, M., N. Malik, T. Khan and M. Faridullah. 2011. Effect of solid waste on heavy metal composition of soil and water at Nathiagali-Abbottabad. Department of Environmental Sciences, COMSATS Institute of Information Technology, Abbottabad. Pakistan. 
Islam, M.S., Suravi and N. T. Meghla. 2010. Investigation on water quality in the Ashuliabeel, Dhaka. Bangladesh J. Fisheries Res. 14(1-2): 55-64.

Jackson, M.L. 1973. Soil Chemical Analysis.Prentic Hall Inc. Engle Wood Clitts, N.J. USA.

Kibria, M.G., C. Quamruzzman, A. S. M. W. Ullah and A. K. M. F. Kabir. 2012. Effect of longwall mining on groundwater for underground coal extraction in Barapukuria, Bangladesh, J. Mines, Metals \& Fuels. 60: 60-66.

Rahman, A.K.M.L., M. Islam, M. Z. Hossainand M. A. Ahsan. 2012. Study of the seasonal variations in Turag river water quality parameters. African J. Pure and Applied Chem. 6(10): 144-148.

Tandon, H. L. S. 1995. Methods of analysis of soils, plants, waters and fertilizers.Fertilizer Development and Consultation Organization, New Delhi, India. pp. 87-92.

Tisdale, S.L., W. L. Nelson, J. L. Halvinand J. D. Beaton. 1999. An introduction to nutrient management- Soil fertility and fertilizers, $6^{\text {th }}$ edition, The Prientice Hall, New Jersey, 52-278.

Tiwary, R. K. 2001. Environmental Impact of Coal Mining on Water Regime and Its Management. Water, Air, and Soil Pollution. 132: 185-199.

Trivedi, R. K. and P. K. Goel. 1984. Chemical and biological methods for water pollution studies. Karad Environmental Publication. pp. 1-251.

Wang, Q., Y. Dong, Y. Cul, X. Liu and Wang-Qingrin. 2001. Instances of soil and crop, heavy metal contamination in China soil sediment contamination, Yanki press. 497-510.

Walkley, A. and I. A. Black 1934. An examination of the Degtjareff method for determining soil organic matter and proposed modification of the chromic acid titration method. Soil Sci. 37: 29-38. 